\title{
The Interface between the State and Civil Society in Nepal
}

Chandra D. Bhatta

\begin{abstract}
The paper explores the state-civil society relations in Nepal, which have gone through many ups and downs from various perspectives. This is important for the reason that the two terms are now in the forefront of public debate: Rajya - the state and Nagarik Samaj civil society. Voices, both in favour and against the state and civil society, are now audible everywhere. The debate has picked up momentum, particularly after the regime change of 2006, when civil society took a new birth and played a crucial role in regime. However, all is not well with the role of both state and civil society. The point at stake, however, is how should one describe the statecivil society relations in Nepal; how they influence, behave, and view each other; and where do they converge and diverge? These are some of the important issues that need to be looked into carefully. The rise of right-based civil society organisations (CSOs) in Nepal has further created confusion vis-a-vis state. Within these contexts, paper here attempts to explain the extant interface.

Keywords: civil society, Nepal, CBOs, democracy, societal values
\end{abstract}

\section{Introduction}

This paper examines the state and civil society relations in Nepal which have taken the centre stage in recent years. The two terms are now in the forefront of public debate as citizens at large blame 
Rajya, Nepali equivalent of the state, for its multi-fold failure and insist Nagarik Samaj, the Nepali equivalent of civil society, to take the lead role and rescue it. Voices, both in favor and against the state and civil society, are now audible everywhere. The debate picked up its momentum, particularly after the regime change of 2006, when civil society took a new birth. The debate on the state - the agenda of restructuring it - is also raging, though it has not been sufficiently discussed in the academia and the political circles. The paucity of literature on the relationship between the state and the civil society raises the queries: How can one describe the state-civil society relations in Nepal; how they influence, behave, and view each other; and Where do they converge and diverge? The proclivity is to regard civil society as a 'pole of virtue' and the state as an 'incarnation of evil'. This has gone unabated with the rise of the right-based civil society organisations (CSOs).

There are also attempts to vilify the image of the state, the culture, and the tradition of the land and to rehash the nation's history after the Unified Communist Party of Nepal-Maoist (UCPN-Maoist) joined the political mainstream through the 12-point agreement signed in New Delhi on November 2005. With Monarchy abolished, conflict has now shifted toward the state and such conflicts, to a great extent, are being used to dismantling its ancient foundations as well as its symbols, dress codes, and values. Baburam Bhattarai, in one of his articles, categorically argues that there is an urgent need to demolish the existing 'state structure' to break away from the past $^{1}$. There are sizeable numbers of opinion makers, CSOs, and human rights organisations (HROs), who squarely blame the state for representing a certain group of people, particularly the Khasa (Bahuns and Chhetris). The question here is: Does it really exist and if yes, how has it survived as one of the oldest nations of the world?

Theoretically, civil society and the state cannot be neatly bounded off or insulated from each other, since the former requires a political and legal framework institutionalizing the normative prerequisites of rights, freedoms, and rule of law and the latter requires a certain legitimacy which it acquires from the (civil) society. The state

1. See Interview with Comrade Baburam Bhattari, World People's Resistance Movement, available at http://www.wprmbritain.org?p=926, accessed 4 September, 2012. 


\section{Dhaulagiri Journal of Sociology and Anthropology Vol. 10, $2016 \mid 65$}

provides the necessary legal framework, such as constitution, judiciary, and even the police, quintessential for any meaningful implementation of civil rights, which arguably constitute the core of civil society. The reference point to understand the state is outside the domain of the institution sensu strictu, that is, in civil society (Chandhoke,1995, p.9). This really brings us to the next question: What is the state and civil society? While it is not within the scope of this paper to define them precisely or fully, which would require more space and time than available here, still one could say states are much more than just governance which set the political discourse and politics, in short, is about the dialogue and contestation that society has with the state and the site at which these encounters take place is civil society (Chandhoke, ibid).

The true nature of the state can be understood in terms of its relationship with various elements of society. What is important here is what traditions it follows, how it interacts with such elements including political parties, market, and donors. Civil society, for its part, can only be understood by referring to its actions and attitudes toward the state and society at large - whether it is working as a pool between the private and the public sector or not? What is important in the case of civil society is what it does and who it works for. In order to understand the relationship among the three orientations of civil society -the actor, the functional, and the sociological, for the theoretical framework, it will be more appropriate to focus on the actor-oriented approach as action determines the degree of civility of civil society and the perception of the broader society toward it. This also settles its relationship with other actors.

In fact, the theoretical framework for the state-civil society relationship in its current manifestation is rooted in the neoliberal assumption that private/market initiatives are always preferable to the state actions. The adoption of this approach particularly after 1990 in Nepal led to the growth of civil society, whose main actors are NGOs, but not necessarily strengthened the state-civil society relations. This is primarily because this approach gave birth to the CSOs who are not embedded in broader society. This has separated what Migdal calls the state-in-society approach (Migdal, 2011). The paradox is such that the state is embedded in the societal and cultural practices and rooted in the broader social traditions while 
civil society formed thus is completely alien in nature. This perhaps could be the reasons, among others, why that as Nepal moves towards democratisation process the state-civil society relationship seems to have been strained ${ }^{2}$ and interface between the two is found somewhat paradoxical in nature.

Based on my own reflection and experience working in this field and opportunity to have interaction with various stakeholders in scores of seminars, discussions, conferences, and workshops organised in national, regional, and local levels ${ }^{3}$ gives me the strength of understanding such debates and put them under the theoretical context. The major argument here is that in recent times, particularly after the political change of 2006, the relationship has worsened and many of the modern CSO, who earlier thrived on the neoliberal policies of the state, have generated more problems than providing solutions to the extrapolated politics of Nepal. In order to explain the relationship between the state and civil society, the article has been divided into various parts. The first attempts to deal with the concept of the state and civil society in Nepal. The second part discusses the interface between the both at the different time frames. We also discuss how the increased numbers of CSOs have impinged upon the role of the state followed by the conclusion. It is, however, yet to be seen that how state would be constituted by political agendas drawn up by the different sections of civil society as there is no consensus on the exact nature of the state.

\section{The State and Civil Society in Nepal}

2. The situation arose primarily because many of the CSOs are found to have been not working in line with the priority of the state. They have defined development, democracy, and social inclusions on their own terms are found operating throughout country without prior permission the state. There are more than 200 INGOs operating illegally in the country and government believes that they are promoting the civil society that enhances their interests.

3. Right after the political change of 2006, I have had an opportunity to be involved in such activities wherein the discussion on the relationship between the state-civil societies took the centre stage. During the period of time the author conducted and directly involved in more than 400 seminars participated by 4000 plus people in various parts of Nepal. 
States (Rajyas) are as old as the Vedas, most of them appearing as lineage 'states' in South Asia in the Gangetic belt and Himawat Khanda (Thapar, 1984), and developing over time to become modern states. The state of Nepal emerged after the unification of petty principalities in 1768 by Prithvi Narayan Shah, as one of the $17^{\text {th }}$ oldest on the world map with resiliency as its key characteristic evident in its ability to survive centuries of imperial onslaughts and a number of system crises in the course of its evolution (Deutschcited in Aditya, 2010). In a nutshell, we can argue that it is an ancient, traditional, and resilient state. It is diverse in cultural values and its cultural boundary has expanded beyond the border. While one could argue that historically neither the state nor the civil society tried to encroach on each other. However, the state-civil society relations have deteriorated over time, one reason being the emergence of the right-based liberal civil society ${ }^{4}$ and its 'activities' in a faith-based and duty-bound society; another, the fusion of the reason-based Western intellectual tradition with the spiritual Nepali scholarship. Such an approach undermines the feeling of emotionalism which ultimately de-linked the state from the society (Dahal, 2010). In fact, the governance and the guiding principles of the state, before the arrival of the modern idea of it, was regulated through the unwritten scripts of society based-on certain traditions/values. Unlike the Weberian concept of the state which is largely based on the legitimate monopoly on violence - the state in the Vedic period (down to $600 \mathrm{BC}$ ) had a duty to maintain peace, order, security and justice in society and in post-Vedic period the duty of the state was to promote Dharma, Artha, Kama, and Moksha (duty, wealth, work, and Enlightenment). These ideas included the all-round moral and material progress of the individual and society. This trend continued until the sub-continent adopted the modern governance systems. Such historical approaches have shaped the notion of delivering justice on the basis of Paap (sin) and Punya (good deed) or Satya (truth) and Asatya (untruth) till today ${ }^{5}$. Under such conditions, it is

4. Their main activities remained in advocating the rights of various groups from the state but not their duty towards state and society for that reason.

5. Ranas who ruled Nepal for more than 104 years had always upheld dharma while delivering justice. Even before that there has been a saying that if the justice is denied goes to Gorkha (Nepal). 
not really a matter of concern for the large number of people - who live in the rural Nepal - they are less concerned with the institution of the state also with the constitutional process ${ }^{6}$. The moral codes govern their private and public life. The modern CSOs/NGOs do not necessarily understand this dynamics and blame both the state and society as 'uncivil. The extant tumultuous relationship between the two is the product of this gap.

In a global sense, the history of state-formation is studded with acts of compromise, aggression, and expansionist overtures and Nepal certainly is no exception. But in assessing the nature of the Nepali states, one also comes across opposite maxims that offer a more positive image. One is Nyaya napaye Gorkha janu (Go to Gorkha if justice is denied) which captures the just nature of the Nepali state. The Dibyopadesh (treatise) does not lack in such adages. Prithvi Narayan Shah is said to have made Kalu Pandey his Prime Minister (Bada Kaji) against his own choice Biraj Bakheti. Among his advisors was also Bise Nagarchi - a tailor by profession- a reflection of the degree of acceptance and representation of people's voice in the politics of those days. Yet, there are people who only fault the state for the way it evolved over the centuries?

Nepali state has become a 'weak' state due to chronic governmental instability and occasional conflicts since its unification among the courtiers, political classes who are found to have been vying to control both political power and the polity (Upreti, 1992, Acharya, 1998). It has witnessed intermittent regime changes after unification. To illustrate, after its formation the Shah Kings ruled Nepal but later Jung Bahadur Rana took over power from the Shahs and introduced the hereditary rule (agnate system) of the Ranas which ended in $1950^{8}$ when democracy was established. But it was short-lived due 6. During the recent electoral campaign the major demand from the part of the people was not constitution. They argued that our forefathers did not have constitution but they have strong state but with the constitution in place, we have become weakest state in the world. Their major demand was development that can alone restore the real sovereignty of the state.

7. There are opinion makers and self-declared members of civil society who are engaged in tarnishing image of the state.

8. From 1768 to 1846 Shahs ruled Nepal. In 1846 Nepal fell under the sway of hereditary chief ministers known as Ranas, who dominated the monarchy isolating the country from the outside world for 104 years. 


\section{Dhaulagiri Journal of Sociology and Anthropology Vol. 10, $2016 \mid 69$}

to the rivalry among the political parties and the power was usurped by the King who introduced the Panchayat system in 1961. Another regime change took place in the 1990s through popular movement and multi-party democracy was reinstalled. Nepal again witnessed a regime change in 2006 that initiated the process to remove the Shah Dynasty and became a republic in 2008. The push and pull factors from various quarters have rendered the state fragile and we can see a steady decline of state authority which seems to have moved toward the political parties, their sister organisations, militant party wings, and other non-state actors.

As in the case of the state, the tradition of the civil society is older than the modern Western concept of civil society. In that context, Katju (2012) says that thousands of years ago the people living in the Gangetic belt and Himawat Khanda built a mighty civilisation when most people in Europe (except in Greece and Rome) lived in the forests. Theoretically, if the word 'civil' implies tolerance and accommodation of pluralism and diversity, then one can find those values in the Vedic society. The collective approach based on the shared values of Sanatan Dharma ${ }^{9}$ kept the society together for centuries. Principally, the philosophy of Sanatan Dharma is one's own duties in an individual sense, but globally, it means the universal law by which we all are bound together. Driven by this philosophy, the development of public sphere such as Ashrams (common homes for sages), Dharmasalas (common resting places for travellers), Gurukuls, and Pathasalas (residential schools) could be seen spread all over the Gangetic belt and the Himawat Khanda.

The dharma ${ }^{10}$ based civil society and the traditional CSOs rooted in societal values promoted the public space with equal access

9. Sanatana Dharma, the original name for Hindu Dharma, which is anadi (without beginning) and a-paurusheya (without a human founder) and is defined by the quest for the cosmic truth, just as the quest for physical truth defines science, was first recorded in the Rigveda, (the record of ancient sages who tried to learn the truth about the universe, in relation to Man's place in relation to the cosmos).

10. Dharma is not identical to religion (the equivalent English translation). Dharma, as per the Vedic script, is the way of life and has no end nor a beginning (anadikal). It is said to have existed since before the earth came into existence. 


\section{0| Chandra D. Bhatta}

for all. In fact, dharma-based civil society and pre-NGO civil society organisations, which could be regarded as 'old' CSOs (student unions, lawyers' associations, trade unions, journalists' and cultural groups etc) historically played a decisive role in the struggle for democracy to protect Nepali nationalism, for building the democratic society and ensuring the civil rights. These CSOs nurtured the Nepali state and societal values in contrast to the public space created by the 'new' right-based CSOs/NGOs who promote the superiority of one civilization over all others ${ }^{11}$. In that sense, they were probably more ethnocentric. The new NGOs with their liberal and Marxist orientations have had multiple impacts on Nepali society: their liberal values may not necessarily be salutary for a country like Nepal and secondly, the engagement of externally promoted NGOs could well dilute the state's sovereignty. Moreover, CSOs funded largely by the international donors usually diminish their effectiveness, since he who pays the piper calls the tune.

Those CSOs/NGOs and intellectuals advocating civil society from the Marxist perspective tend to radicalise the broader society ${ }^{12}$. They work in the Marxist, Leninist, or Maoist traditions but the broader Nepali society is spiritual (dharmic) and believes in the trinity of three Hindu gods: Brahma, Bishnu, and Mahesh. The right-based civil society organisations in towns, either promote market materialism or dialectic materialism - whose tacit objective is to weaken the very core of the traditional state by using the rich against the poor or poor against the rich. None of these CSOs create opportunities for the 'commoner' to express their grievances with the state and its official agencies. The civil society and the political society have, as a consequence, turned citizens into their cadres and used professionals, intellectuals, experts, and the opinion makers have now are the main constituents of 'public sphere' - for their own personal benefits ${ }^{13}$ thereby consolidating clientele-state relationship.

11. Majority of the externally established CSOs/NGOs in Nepal are pitting one community against the other and this has become frequent in the recent years.

12. The human rights organisations are front runner in this regard.

13. The mobilisation of media, by certain publication houses, which is part and parcel of the "public sphere" against the government's recent decision to demolish illegally built public properties is one classic example. For details, see 'Nirankushatako Priya Bistar' in Himal Khabar Patrika, 31 
In such a state of affairs, most of the time state largesse used for mutual benefit. Voices and groups who differ are not heeded and the Janata (people) becomes a passive, silent spectator, an object of "exploitation" in this whole process. Under such conditions, it becomes difficult to define and differentiate civil society from other societies given the diversity of nature, function, character, and identity (Bhatta 2012; Dahal 2001).

\section{The State-Civil Society Interface}

The relations between the state and the civil society, both in their traditional and modern forms, are quite confusing. In consolidated democracies, the relationship is formal, more stable, and predictable but the same is not true in the transitional societies where it is in flux most of the time. The state-civil society relationship can be analyzed from different perspectives such as cooperative, competitive, complementary, oppositional, and neutral. In the context of Nepal, since it witnessed multiple regime changes over the years, and most of the time civil society was seen as instrumental in these events, the relationship demands a close look into the various phases of its evolution to obtain a realistic view of its mode of growth and change. While analyzing the interface one has to understand, at the outset, that states try to maintain order in the society and civil society, for its part, looks for 'more freedom' and striking the right balance between the two can reduce tension in the broader society. In the context of Nepal, we can see several instruments to facilitate the interface, mediate the tension, and create the synergy in various ways. We could see at many times harmonious relations between the two. The state has designed suitable polity at different levels of governance (from the center to the village level) ${ }^{14}$ for smooth interaction of civil society with the state. During the olden times the interface used to be set by the rulers, on the basis of DharmaPunya (good work) and Paap (bad work). It was Dibyopadesh that established the social contract between the state and the society during Prithivi Narayan Shah's rule. During the inception phase, as mentioned below, it was the Muluki Ain (Civil Code and later

December 2011-14 January 2012.

14. The 'Citizens Charter', developed by all government offices and the appointment of Information Officer in the government offices are two recent mechanisms developed for the interface between the two. 


\section{2| Chandra D. Bhatta}

through the constitutions, legislature, courts and alike) mediating the interface. The constitutional state induced the polities at various levels to strengthen the interaction, if with some ups and down, in the various phases of the nation's history.

\section{Inception Phase 1900-1960}

Nepal has had a long tradition of civil society15.However, civil society in its current form emerged after the year 1900 when the country's politically docile society started rallying against the Rana regime. One can see the effervescence of the state-civil society interaction in different forms during this period whereas, it lay in a dormant stage before, as both the state and the civil society were largely controlled by the ruling elite of the Rana regime and there was very little opportunity for interaction with the state. As the Ranas were reluctant to open educational enterprises, the formation of critical mass was not possible for the growth of an independent civil society. The main role of the class of dissidents was to overthrow the regime for which it needed to increase its outreach in society. The overarching aim was thus to separate the elites from the state and bring them closer to the people in general. The state and the system were both controlled by the Ranas and the King Tribhuvan who was the Head of the state, was virtually left out. The King aligned himself with people for the installation of democracy. During the Rana regime, it was difficult to establish formal organizations of civil society. However, two types of civil societies' groups could be seen as emerging simultaneously: political and social with distinctly separate purposes. The job of the political society was to prepare the ground to overthrow the Rana regime and establish democracy whereas the social agencies were working for social reform through education to promote the notion of voluntarism and civic values in society. The interesting point is that both were governed by the norms of Dharma (duty).

On the social front, Arya Samaj (a civil society organization) set up by Madhav Raj Joshi in 1909 was the first civic organization which came up to introduce social reforms by removing deeply entrenched fallacious beliefs and social stigmas from the society. Daya Bir Singh Kansakar established Paropakar Sansthan (a

15. Ibid. 


\section{Dhaulagiri Journal of Sociology and Anthropology Vol. 10, $2016 \mid 73$}

charity association) to promote voluntarism and civic service and Tulsi Mehar established Nepal Gandhi Charkha Pracharak Samiti (a committee to promote the spinning wheel). These civic initiatives were designed to transform the society, educate people to live a selfsustaining dignified life, and enhance civility in society.

On the political front, in 1920, Subba Krishna Lal Adhikari wrote Makaiko Kheti (Maize Farming) - a satirical work against the Ranas. It also aimed to uplift the poor. In 1937 Nepal Nagarik Adhikar Samiti (Committee for Citizens' Rights) was set up to generate public consciousness against the Rana oligarchy. The members of the Nagarik Adhikar Samiti (citizens rights committee) chanted slokas (verses) from the Bhagwat Gita as a form of protest against the regime and encouraged people to struggle for democracy ${ }^{16}$. Nepal, in those days could not remain aloof from the wave of democratic ideas that spread after the Second World War.In the year1939, Nepal Praja Parishad (Nepal People's Council) -- the first political party in the country--was formed (some of its members were executed) which started the movement to abolish the Rana regime. The Jayatu Sanskritam movement (Hail Sanskrit, 2004 B.S.) was another historical campaign launched for the democratic development in Nepal. The labour strikes that broke out at the Biratnagar Jute Mill in 1947 was also prominent movement against the Rana regime.

During the same time, organizations like the Gorkha League operating in India were publishing materials to raise the level of public awareness about the state inside Nepal amidst Nepali migrants living abroad. They also frequently used to travel to Nepal. Varanasi used to be the center of politics and source of knowledge in those days where people from all walks of life convened and discussed politics ${ }^{17}$. The movement against the Ranas was influenced substantially by the Indian Nationalist Movement-the Indian National Congress, in fact, was one key source of inspiration for the Nepali Congress. The

16. Shukra Raj Shastri (who was among the four martyrs) played crucial role in generating consciousness among people about democracy and civic rights.

17. Varanasi, in India, was not only the center of politics; it was also a center for knowledge and a religious site for all Hindus. The politics that grew in Varanasi was guided by Dharma. The decline of Varanasi and rise of Delhi in Nepali politics marked a qualitative change in the tenor of Nepal. 


\section{4| Chandra D. Bhatta}

educated middle classes at home and abroad were at the forefront of political and social movements.

The Rana Regime collapsed in 1950 when organized political parties, civic associations, and people at large played a crucial role. During the Rana rule, educational exercise and "enlightenment" of masses remained a taboo. Ranas preferred to keep the people in dark and secluded from the rest of the world. Theirs was mainly a law and order regime. All said, however, Ranas got back the Western part of Nepal (Naya Muluk) from the British India, abolished slavery and Sati system (widow immolating), and initiated social reforms in many areas. They also created space for the growth of modernity-constructed modern buildings, opened educational institutions (such as the Tri-Chandra College), opened Hospitals (Bir Hospital), established a hydropower plant in Pharping ${ }^{18}$, and launched the first newspaper in the year 1901 (Gorkhapatra). Ranas also introduced Muluki Ain (Civil Code), when very few countries in the world had such a code for the interface of the state with (civil) society. One could claim that Ranas (in) established reason of the state and formally started the state-building process. They however, could not make any distinction between the private and public spheres which later became the main concern for the enlightened persons within and outside of the regime. With the end of that regime, Nepal entered a new era of democratic politics wherein the source of authority was defined in terms of popular sovereignty and women were granted adult franchise. All this provided a conducive atmosphere for the expansion of civil society organizations. The limited numbers of educated Nepalese acted as the backbone of civil society who later got either absorbed into the state apparatus or party structures. This initial resurgence of civil society was not aimed at overthrowing the state or contravening its objectives, hence the issue of a manifest conflict with the state hardly arose. In reality, some sort of complementarities could be noticed in those days between the state and the civil society.

\section{Opening Phase 1960-1990}

18. It is matter of pride to know that Pharping is the second hydroelectric project in Asia and there was no electricity even in China and Darjeeling was the only place with electricity at the time. Taj Mahal hotel in Mumbai (the first building to have electricity) had electricity only in 1903. 
The royal putsch in December 1960 ended multi-party democracy which was replaced by the non-partisan Panchayati model of democracy. With the promulgation of the Panchayat Constitution in 1962, people's fundamental rights and freedom of association were partly curtailed. There was no restriction on the free movement of people in the country - they could assemble but restrictions were placed on political gathering that directly opposed the state institutions and the political system ${ }^{19}$. Interestingly, Panchayat banned oppositional politics but allowed a semblance of democracy at the grassroots level with regular elections ${ }^{20}$. The self-styled Panchayat democracy set up six class organizations: youth, women, peasant, ex-army, labour, and senior citizens as the core partners of the party less regime. These agencies were setup primarily to function as 'civil society'. Interestingly, unlike the Rana regime, Panchayat expanded the sphere of the government, enlarged the elite base of the system, and initiated the process of social mobilization of people at the grassroots level (Dahal 2001, pp.29-30). It also promoted the public institutions and practiced the notion of the welfare state to increase the access of people to the state resources (Dahal, ibid). This was done through the local government institutions for the increased interaction of citizens with the state. Academic and research opportunities were integrated into the national mainstream providing ample space for the growth of a certain critical mass. Think-tanks like the Centre for Nepal and Asian Studies (CNAS), Centre for the Economic and Development Administration (CEDA), and Royal Nepal Academy for Science and Technology were also established to provide policy inputs.

The Panchayat adopted a sort of benevolent attitude toward culture, education, and media. The introduction of the New Education Plan in 1972 is a case in point. The rulers tried to instill the feeling among the people that Panchayat was the only option for democracy, development, and survival of the state and the most compatible political system for Nepal with no 'alternatives'. The rulers tried their

19. See the Constitution of the Kingdom of Nepal, 2019 B.S./1962 A.D.

20. During thirty years of the Panchayat rule it held regular elections both for the central and local bodies which have not been the case now (the democratic era). Nepal has not hold elections for the local bodies for more than 15 years now. 


\section{6| Chandra D. Bhatta}

best to win people's loyalty toward the state. One classic instance to illustrate the point came in the 1989 economic blockade imposed by India. As the highest representative of the state, the King used to travel outside of the capital every winter when he interacted with the local people to get the firsthand information from the society.

During this period the state did not try overtly to control the society, but its focus was on depoliticizing citizens by putting a lid on the formal operation of political parties and their activities. In order to encounter the global wave of Western NGOs- who had multiple agendas in the name of democracy and development - it established the Social Service National Coordination Council to regulate the NGOs. Accordingly, all the NGOs were required to register with it. As per the Association Registration Act 1977, the Chief District Officer (CDO) would register, guide, direct, control, and supervise social organizations, i.e. clubs, public libraries, literary societies, self-help groups, NGOs, even cultural groups. Some analysts have regarded the approach hegemonic, but the reality was somewhat different. We have to remember that nowhere in the world the NGOs and INGOs have as much freedom of action as here in Nepal which is now becoming even counterproductive ${ }^{21}$.

King Birendra, who was relatively liberal, allowed political societies to exist; they were only subjected to coercive measures when they become openly hostile to the regime. The Panchayat system permitted the formation ofa certain critical mass of opposition, but there was no adequate place for its active engagement in the political life of the state (Dahal, 2001). It was this mass that later divided along partisan lines and rose against the regime and forced the government to call for a referendum in 1980 . While the Panchayat was slowly opening up with the third amendment of the Constitution following the referendum, the late 1980s initiated the televised mode of mass communication that brought now the winds of change to Nepal. The liberal Panchas and other organizations started developing their alliances with political parties who rose against the Panchayat Regime (not the state as such). By and large, the political society

21. The freedom enjoyed by the NGOs in Nepal is such that they can even order to government and can operate in the areas of their choice such as national security. This is so because most of the NGOs are operated by influential persons. 
galvanized its strength in the urban areas including the broad sections of the society compared to the pre-revolutionary days of 1950 . Alongside the political parties, student unions, teachers, professors, professional associations (lawyers, doctors, and engineers), writers, and artists participated in the mass movement of 1990.

After the referendum of 1980,a new form of civil society organizations surfaced consisting of professionals from diverse streams. This was partly because there was no legal barrier in holding debates on alternative mechanisms within or outside the Panchayat system, openly and freely. Stringent provisions of laws were relaxed or amended to facilitate the freedom of expression. Ideas against the Panchayat System emerged as did advocacy of the multi-party and pluralist concepts in the academic circle. The only restriction that remained was on efforts to capture the government on the basis of ready-made externally floated ideologies. This new pluralistic resurgence was influenced by the third wave of global democratization which brought together all sorts of ideologies (leftist and rightist) into a common platform ${ }^{22}$. In Nepal, the coming together of political parties of all sorts including the liberal Panchas (who collaborated clandestinely with other parties in the movement) into the broader democratic framework and formation of various types of professional groups consolidated the resistance against the regime in power. During this phase, monarchy made democracy and economic advancement its twin goals ${ }^{23}$ and defined 'development' as apolitical. It was this time when major infrastructures were established and Nepal firmly established itself in the international arena through its proactive foreign policy approach ${ }^{24}$.

Coincidently, this phase also witnessed a shift in the global policy for example, many countries were forced to adopt liberal democracy and an appropriate economic policy to support it. Accordingly, they were asked to accept structural adjustment programs (SAP)

22. The launching of the joint movement to reinstall multi-party democracy by Nepali Congress and United Left Front is a classic example to this point. 23. Sharma, 1989, p.30

24. The major infrastructure such as the East-West Highway (Mahendra Rajmarga) and establishment of Nepal 's unique identity through Zone of Peace (ZoP) proposal (which was supported by 114 countries) is the case in point. 


\section{8| Chandra D. Bhatta}

conditionality put forward by the international agencies such as the IMF. Nepal could not remain untouched and adopted SAP conditionality whose main focus was more representation of the stakeholders in the development process for which NGOs were thought to be the best option. The Nepali state was left with no option other than opening up more NGOs for service delivery in the social sector. The operation of NGOs was largely controlled, yet, rules were often relaxed for them to work. The consequences of the liberal development policies of the 1980s were also reflected in politics. The problem was that while the regime adopted liberal economic policies, a liberal education system, and partly liberal political system, the process of political opening up moved at too slow a pace after the referendum. This was the opportunity political parties in opposition were waiting for which they seized to revolt against the Panchayat system in 1990.

Most of the professional associations, such as students, teachers, university professors, lawyers, doctors, engineers, journalists, and others aligned themselves with the political parties having identical ideological/political orientation. Some of them aligned with Nepali Congress (NC) and others with Communist Parties of that time ${ }^{25}$.The gap between political society and civil society was expunged by the party affiliated human rights organizations. The five new agencies that came up - Democratic National Unity Forum, National People's Forum, Civic Rights Forum, People's Right Protection Forum, and Human Rights Protection Forum in 1985 by the Communist Party of Nepal (ML, later renamed UML) - illustrate the point just made. Civil society groups thus formed were completely different in their nature and scope. While the earlier civil society groups were mostly operating in the social space - there was a clear notion of charity and voluntarism-the new civil society agencies were civil in word but more political in their objectives ${ }^{26}$.

The civil society's rise against the Ranas was spontaneous contrary

25 . Not only are the professional associations the human rights organisations are vertically divided on partisan lines.

26. This is so because majority of them are partisan in nature and there is also no clear boundary between 'civil society and political society' in Nepal. See for details C.D.Bhatta,'Unveiling Nepal's Civil Society', Journal of Civil Society (2012). 


\section{Dhaulagiri Journal of Sociology and Anthropology Vol. 10, $2016 \mid 79$}

to the civil society that emerged after the late 1980s which was externally driven both in its ideology and action. The democratic pluralistic initiative (DPI) taken by the US, particularly after the fall of communism in Eastern Europe, played a crucial role in shaping the new types of civil society in this part of the world as a foreign policy tool not to promote the citizenship values or strengthen democracy in a real sense of the term. The rise of the HROs could be seen as part of this project. Interestingly, these organizations appear to have advocated democracy and rights but at the same time they, too, have brought erosion on sovereign power of the state and regime for that reason. The common factor between the outlawed political parties and civil society was that both operated outside the state structure and shared a common ambition of installing democracy. Accordingly, the politically indoctrinated CSOs along with professional/occupational groups belonging to political parties of different hues formed a joint front against the Panchayat Regime to launch a movement in 1990. The profile of all the 89 founding members of Nepal Human Rights Organizations, founded in December 1988, clearly revealed them as a common forum of the different ideological camps. The way civil society was formed and used for the cause of regime change would leave a far reaching impact on the new civil society emerging in Nepal.

This phase was marked by concentration of power in the hands of the state, which imposed its authority on the organizations of civil society. It only promoted organizations that supported the regime and suppressed other politically motivated groups, such as trade unions and political parties (though they were working underground - it was acceptable to have an office, use state resources such as postal services, telephone, electricity, water etc.). During this time, two types of organizations existed: regime-supported and the traditional ones. The oppositional political space was occupied by student unions, and other informal groups which worked, as a barometer of regime change, with the rights-based organizations. If the 1980 referendum was the one consequence of all these collective developments, another was the movement of 1990. In a real sense of the term, it appears that, Panchayat did not openly promote any 'ism' that is, liberalism or 'socialism'. It basically promoted 'nationalism' (though it has been debatable at some point). Both development and politics were tied with 'nationalism'. What is true though is that the 
Panchayat consolidated Nepal's position as a state in international arena, and increased the state's outreach in society which could be interpreted in various ways.

\section{Liberal Phase 1990-2005}

In 1990, Nepal entered the multiparty democracy system following the success of People's Movement for Democracy (PMD). The Constitution of 1990 was regarded as, in view of the times, one of the most liberal constitutions extant, as it guaranteed a number of rights and basic freedoms, such as the right of association and freedom of expression ${ }^{27}$. This phase witnessed a vibrant flourishing of modern $\mathrm{CSOs}^{28}$. The publication of daily newspapers, as well as weekly and monthly magazines, in English and Nepali languages from the private sector provided an opportunity for common people to participate in the broader political and social discourse. The registration of NGOs was deregulated and the Social Service National Coordination Council (SSNC) was restructured and its role redefined with the promulgation of the Social Welfare Act in 1992 which provided a mandate to facilitate, promote, and mobilize NGOs in diverse areas. The democratic opening of 1990 also coincided with the liberalization process which emphasized the role of the non-governmental and private sectors in service delivery and development.

Moreover, the Ninth Five-Year Plan (1997-2002) underlined the importance of NGOs, civil society, private sector, and locally elected bodies in social mobilisation. The introduction of Local SelfGovernance Act (LSGA) further encouraged the formation of NGOs and civil societies in local development. These provisions and legal frameworks reinforced the role of CSOs to help the state to discharge duties toward society. CSOs/NGOs thus formed worked in tandem with the state in a number of areas including education, health, public awareness and their contribution was found noteworthy. One can safely conclude that the reinstallation of democracy in 1990 included impressive "societalisation of state," to use Habermas's

27. See Preamble of the Constitution of the Kingdom of Nepal, 1990.

Available at www.lawcommission.gov.np.

28. During two years time (from 1990-1992) 1200 NGOs were established in Nepal. 


\section{Dhaulagiri Journal of Sociology and Anthropology Vol. 10, $2016 \mid 81$}

words. Today there are more than 30,000 CSOs/NGOs operating in the country who have in one way or the other left their impact on 'civil society' in the country.

The change in the policies and practices of the international agencies along with NGOs left a certain impact upon Nepali state. Policy makers were asked to reduce the role of the state and bring civil society into the developmental sphere. Thus, there were two forces which led to the proliferation of civil society groups in the country: political as well as developmental discourse. This encouraged civic activism in the political sector and increased the pace of service delivery through CSOs/NGOs in the initial years of 1990s which had started to form networks in various sectors for political, social, and developmental efforts.

In the initial post-1990 period, the CSOs and the state worked together on many important issues related to national development. The rights-based CSOs, however, presumed that in certain sectors it was essential to monitor and challenge the state to ensure that new policies were adhered to uplift the excluded and marginalized sections of the society such as women, dalits, and janjatis (ethnic groups). Accordingly, during this period, many of the CSOs/NGOs diverted their programs from developmental works/service delivery to work with the state agencies, toward 'awareness' generating campaigns on diverse rights-based themes. This gave birth to a new social movement in the country and also various rights commissions/ networks (Human Rights Commission, Women's Commission, Dalit Commission, Nepal Federation of Indigenous Nationalities, NEFIN, Commission on Bonded Labor, and many more. The actors involved in the new social movements ${ }^{29}$ became the main actors of the civil society. With the rise of the new social movements, the pressure on the state was mounting to address the multiple demands from different quarters. On many occasions the state did not have the capacity to address their demands. Some of the disgruntled agents of the social movement aligned with partners who could take forward their agendas. For example, some sided with political parties and shared their grievances and others took their agendas to donors who promised to work for them through their NGOs. By and large, the penetration on the transitional state was deep and multifrontal.

29. Most of these movements were led by NGO personnel. 


\section{2| Chandra D. Bhatta}

This became more evident after Nepali state signed both the human rights covenants (political and economic, social, and cultural) without developing its capacity to deliver. The new CSOs/NGOs who initially thrived on the state's legal framework are now forming their own defacto constitutions with their own rules and regulations by skirting the state ${ }^{30}$.

Amidst all these, the adoption of neoliberal policies provided fertile ground for the 'reincarnation' of Nepal's civil society in the form of NGOs. This also opened the door for the unaccounted/unrestricted flow of foreign money siphoned off by the local elites in the name of development through CSOs/NGOs. Civil society groups flourished to such an extent that many of them began to transgress the state's oversight mechanism while others were busy fomenting the faultlines ${ }^{31}$ by projecting shortcomings in local practices of development, democracy, and cultural values. This occurred primarily because they were not embedded in society as both funding and philosophy for their activities was coming from outside. One scholar argued that it was really not clear whether it was the development of development or development of NGOs (Shah, 2003). In fact, the urban-based civil society and media treated the state as a medium through which they could fulfill their interests. The treatment of state as an 'object' of social, economic, and political mobilization brought erosion in its Weberian legitimacy (Bhatta, 2008, p. 44). Moreover, withdrawal of the state institutions from the society and dismantling of public institutions under the garb of neoliberal policies left the ordinary people in the lurch thereby turning the society against the state.All this fuelled the Maoist insurgency, compelling the state to tighten its grip on society as a whole. The state declared emergency in 2002 to quell the Maoist insurgency, but people's fundamental rights were not curtailed.

In February 2005, when the King took over the power, the government introduced a new Code of Conduct $(\mathrm{CoC})$ for social organisations stipulating that people working in the NGOs should not participate in party politics, could not head any organisation for more than two

30. The formation of the umpires like Association of International NGOs in Nepal (AIN) and NGO Federal of Nepal is designed primarily to skirt the role of the state.

31. NEFIN could be seen as front runner in this regard. 


\section{Dhaulagiri Journal of Sociology and Anthropology Vol. 10, $2016 \mid 83$}

terms, had to make public their audited financial and yearly progress reports and submit them to the District Administration Office and District Development Committee (DDC), were not to receive monthly salaries and had to get prior permission from the Social Welfare Council (SWC)to receive foreign assistance. During this time, the King also tried to form a pro-government civil society ${ }^{32}$. Rights-based NGOs, who where against these provisions, launched their own movements in solidarity with the agitating Seven-Party Alliance (SPA). The NGO Federation and the Association of INGOs in Nepal also rallied against the state to roll back the code. CSOs, which were opposed to the King's rule, regarded the state as illegitimate. Therefore, much of their advocacy involved them in efforts to overthrow the royal regime. The government, for its part, questioned the transparency, accountability, and performance of the CSOs, whereas civil society leaders argued that the government was all set to weaken them. By and large, the state and the civil society were locked in a head-on conflict during the King's absolute rule.

The restoration of democracy in 1990 brought a paradoxical situation, broadening the space of civil societies on the one hand and declining moral values on the other. This brought multiple problems in society. Jeffery Sachs (2011) who in his recent work, states that declining moral values and civic virtues are responsible for the current crisis [including the financial] in the world, when it becomes impossible to create a mindful society. This probably explains why civil society lacks people's trust in Nepal as they have failed to transform the multiple identities into a common civic identity.

The relationship between the state and the civil society thus is marked by distrust and a general lack of collaborative action during this period. On many occasions, CSOs were absorbed or co-opted by the state and at other times they seem to have worked against the state and societal values. Such an attitude has generated intense conflict between the two. The proliferation of interest groups in civil society has already created a political gridlock to paralyse the democratic process and economic growth ${ }^{33}$. During the 1990s,

32. This was obvious for him as the Kathmandu-based entire civil society groups were against his undemocratic step but there motive was not clear until then.

33. The classic example is the formation of caucus groups across political 
interest groups, political parties, and their sister organizations and other associated groups regularly called for bandas (shutdowns) and pursued political action outside the formal political frameworks/ institutions, which could be regarded as an encroachment of the civil society upon the state for their own demands. In the long run, this became an established practice to exert pressure on the transitional state.

\section{Anti-State Phase 2006 -}

What transpired in the political and economic domain right after the 1990's movement prepared the background for the anti-state phase. The rise of the communist parties and so called left intellectuals (majorities of them aligned with communist parties) - whose aim was to set up a dictatorship of the proletariat, promote nationalism, and fight against imperialism -along with the subsequent arrival of the CSOs/HROs en masse in the Nepali political and public sphere, contributed immensely to the anti-state developments. Both abandoned their constituencies. While the left intellectuals aligned with the NGOs and were subsumed by them, the left politicians joined hands with the capitalist actors. By doing so, both became true agents of neoliberalism in practice but in theory they left no stone unturned in ranting out the slogans of Marxism. None of them cared for the peasantry and working class people for whom they purported to work. Nepali Congress government, too, for its part, failed to work as per the spirit of the political change of the nineties the left political parties and the right-based CSOs who are somehow connected with each other started exposing the fault-lines generating anti-state feelings among the people ${ }^{34}$. The whole unification process of Nepal along with its cultural heritage (Khasa bhasa, Hindu religion, ethnic mosaic) were portrayed as the main reason for Nepal's backwardness and underdevelopment. Some of the international NGOs which arrived with the mission of proselytization in 1990 (Shah, 1993) have succeeded in dividing Nepali society after 2006,

parties in the recently dissolved Constituent Assembly, which virtually displaced political parties.

34. This is interesting in the case of Nepal as majority of the right-based NGOs are operated by the people who are close to the communist political parties and who so the need of dismantling the existing state structure for the new one. 
abolition of monarchy and declaration of Nepal as a secular state. They also succeeded in categorizing the dominant ethnic groups Brahmans, Chhetris, and Dasnamis (who together constitute more than 40 percent of the total population) as the 'culprit groups' and hence included in the 'others' by the establishment ${ }^{35}$.

During the liberal phase, many CSOs/NGOs were successful in securing rights against the state. After 2006, the goal of many of the civil society organizations seems to have been lobbying for the nonstate actors ${ }^{36}$. Ghimire $(2012$, p.8) makes an interesting observation that during and after the 2005 change, the civil society, human rights groups, and most NGOs working for these causes could be seen as either adopting double standards, or behaving purely like anti-state actors. In that process, they have clearly sided with the political parties and actors to demolish and destroy the authority of the state. Most CSOs established in the 1990s have no resources of their own for survival and have reverted to confrontational politics along with political parties against the state weakening in more than one way.

\section{Decline of State and Rise of Non-State Actors}

The steady decline of 'state' can be attributed to various factors but the major one is the crisis on the 'historic identity' on which Nepali state has been built-upon. With the arrival of new ideas such as secularism, republicanism, and federalism after $2006-$ Nepal's political process has become more complicated. There are predominantly two schools of thought running across various quarters of society. One school of thought argues that the new values of secularism, republicanism, and federalism adopted by the post 2006 regimes can and should become the foundation of the state ${ }^{37}$. While the sizeable number of people (whose number is increasing 35. Prakash Chandra Lohani in article "We the People" ( $7^{\text {th }}$ January 2012), published in Republica national daily, claims that 'foreign advisors suggested that it would be best to categorize Bahuns, and Chhetris as 'others'.

36. See International Crisis Group (ICG) report on Nepal's Political rites of Passage, ICG Asia Report No. 194-29, Kathmandu and Brussles: ICG. 2010, p. 22.

37. This statement is largely shared by the modern CSOs and their civil society activists. Also statement made by Shyam Shrestha civil society leader of Nepal. 


\section{6| Chandra D. Bhatta}

in geometric progression now $)^{38}$ argue that these new values have become part of the problem as they run opposition to local culture, values, practices, and self-rule that integrates society ${ }^{39}$. What this certainly ignores is that the first school of thought views the nation and nationalism as largely particularising elements, that is, both are tied to a particular place, experience, people, ecology, and culture. In contrast, secularism, republicanism, and federalism are universal political ideals usually connected to the Enlightenment rationality and science freed from any specific locale or cultural identity. The repercussion of this ambiguity of cultural relationship between the new values and the nation has serious consequences, as experienced by numerous countries across the world, in Nepal as well. Many people are worried that the arrival of new values means the systematic defeat of cultural identity of Nepali state and rise of the non-state agencies who do not necessarily promote or protect such identity (Shah, 2008). In contrary, majority of the CSOs/NGOs are blamed for sabotaging the nation's value system. One can notice large number of civil society organisations, civil society leaders, NGOs, and non-state actors already impinging upon these values. Civil society leaders, political leaders, and elites in the upper echelons of the state organisations act as if they are the sole source of political legitimacy. Promotion and mobilisation of CSOs/NGOs by skirting the state rather than working with it has emasculated its role. The entrenched involvement of especially manufactured CSOs/NGOs in the political process rather than engaging them into civic education roles that could glue society together (such as constitution writing, crafting federal units, and formulating security policies on their own terms)is generating certain level of tension between the civil society and the society at large. Many analysts believe that Nepal is moving towards balkanisation process (Srivastava, 2012). Today, the society at large feels that "manufactured civil society has done more damage to the state than benefits." 40 The relationship between civil societies,

38 . The role of the RPP-N and the voting pattern in the recently concluded CA election should be taken as the classic example to this end. In the recently concluded election many people living in the urban centres voted for RPP-N - the party that demands for referendum on secularism.

39. This is the voice coming from the rural Nepal and also from those who are outside of this network of modern CSOs.

40. This was a statement made by various participants in seminars. The Nepali actors and the international community as well as donors are being 
donors, intellectuals, and state officials seems to have been built on the market model. State officials are found to have been subcontracting state policies to the non-state agencies ${ }^{41}$ encouraging non-governmentalisation of state policies. The rise of what Edward Said (1996) calls the free floating intellectuals and a disciplinebound expert legitimise the position of the non-state actors, weaken the state, and undermines the very notion of citizenship. Equally important is the influence of the trans-national actors, the MNCs, and the intergovernmental organisations which undermined the role of the state. This has been clearly noticed while formulating national policies.

Taken together, the concerted efforts of the CSOs and NGOs along with some donors during this period lay in dismantling the Nepali state $^{42}$. Rather than strengthening the state and its institutions in the post-conflict period, large amounts were doled out to non-state actors to mobilize "public opinion" effectively against the state and its values and "civil society and media were mobilized for this purpose" 43 . One analyst reveals that until 2000 almost all the programs on television, radio, and newspapers were locally sponsored although the situation has drastically changed since then ${ }^{44}$.

blamed for the mess. The Bar Association has asked judges not to attend NGO programs. The CPN-UML, the third largest party, has asked its members to opt for either the party or the NGOs. Not only were donors, civil society, and NGOs clearly visible in the political change that took place six years ago, but they are being blamed for their double standards on human rights and corruption, keeping silent whenever the Maoists are at the center of the storm.

41. Government ministers (including the incumbent Prime Minister himself) were found to have been contracting the security policy of the state to the NGOs. See, for details, the Samacharpatra dated March 9, 2010, Sena Samayojanako Kam NGO Karyalayabat, (Army integration done through NGOs), also Rajdhani National daily, March 15, 2010, (Pradhanmantriko Samayojan Karya Yojana NGO Le Banayako), Prime Minister's Integration proposal prepared by NGO).

42. Majority of the NGOs that were established with outside support particularly after 2006 are engaged in dismantling the social, cultural, and religious values of this state as they believe that they are an obstacle for the development.

43. Again, this is the voice of many Nepalese particularly after 2006

44. Personal conversation with Senior Journalist Dhruba Hari Adhikary, $9^{\text {th }}$ 
There is today a trust deficit between the NGOs and state agencies. The government and the society at large blame the NGOs/INGOs for radicalising society. The NGOs accuse the government as corrupt, and the civil society blames the bureaucracy and the politicians for institutionalising corruption and promoting hierarchy in the society. The recent report of the Transparency International reveals that parties and police are the most corrupt institutions in Nepal. Rather than seeking the help of the state institutions to address their grievances people now appeal to CSOs/NGOs and media ${ }^{45}$.

The government-NGO relationship at present times can be best described as somewhat competitive and, retaliatory not complementary. The CSOS/NGOs are acting like 'sovereigns' on their own and have set up their own empires like the 'NGO Federation of Nepal', an umbrella organisation of local Nepali NGOs, and the Association of International NGOs (AIN), operating in Nepal. Strong alliances with donors/INGOs have consolidated their position in society and CSOs/NGOs use this nexus to bypass the state and its agencies. This phase could well be characterised as a phase of steady erosion of state capacity and disintegration of social order.

\section{Conclusion}

The state and civil society relations in Nepal seem to have gone through many ups and downs and influenced by domestic as well as international factors. Both have had to play various kinds of roles in different timeframes. During the Rana regime, civil society played its role to fight with the Rana oligarchy; during the Panchayat era, the struggle was against the primacy of Shah Dynasty. During the 1990s, civil society secured its position against the state, and after 2006 it has tended to erode the state.In terms of development, during the sixties, state -led development became the model objective; during the 1980s, NGOs were brought into the forefront of development; the roll-back of the state started after 1990, and after 2006 CSOs/

February, 2012.

45. Forty people from Jumla travelled to Kathmandu to report to the office of Kantipur Publications on the corruption of government officials. See Kathmandu Post and Kantipur daily, January 25 ${ }^{\text {th }}, 2012$ for details. 
NGOs prospered at the cost of the state.

The proliferation of CSOs have now produced a surplus of elites who tend to dominate and control both the state and society on their own terms and are merely concentrated in the urban centers. But if the public sphere begins to thrive on states weakness, it can hardly be expected to build a strong society when a weak Nepali state is pitted against the demands from all factors with its capacity to accommodate and address them severely attenuated (Sharma, 2012, p.4).

The future relations between the state and the civil society in Nepal would thus depend largely on as how leaders go about the agenda. If the government and politics get hijacked by the salaried political classes and their civil society by the careerist activists (Bhatta, 2010) for the vested interests, it could end up undermining the whole notion of citizenship. The state-civil society interaction in building citizenship, in the context of Nepal, is best captured in specific models of citizenship such as "consumerism", “clientelism", and "legal citizenship" (Bhatta, 2009). This can only be avoided when the state-society relations begin to redefine the social contract in a new way and foster citizenship values to re-nurture the state from its very roots.

Finally, how does it contribute towards state-civil society theory? At this stage, looking at the case of Nepal, one can safely argue that civil society embedded in the national values and resources can play a positive role in state-building. However, the current circumstances are such where both the state and civil society are externally dependent and one finds it difficult to expect harmonious state-civil society relations in such a state. While the civil society can be expected to work for its agenda vis-à-vis the state for its survival, former may continue to work against the state as long as they do not have their own resources. In such a context, the state must establish its own authority to win people's confidence and support to revitalize the role of civil society in the changing situation in Nepal.

\section{References}


Bhatta, C. D. (2008). Challenges of State building in Nepal. Kathmandu: FES.

Bhatta, C. D. (2009). The Rise and Fall of National Service in Nepal: A Critical Study of Service and Citizenship Building in Nepal. Centre for social Development, CSD Research Report No. 09-30, George Warren Brown School of Social Work. St. Louis: Washington University in St. Louis, USA, 2009.

Bhatta, C. D. (2012). 'Unveiling Nepal's Civil Society', in Dev Raj Dahal and C.D. Bhatta (Eds), Multiverse of Democracy in Nepal. Kathmandu: Friedrich Ebert Foundation, pp140-77 http://dx.doi.org/10.1080/17448689.2012.732429

Chandhoke, N. (1995). State and Civil Society: Explorations in Political Theory. New Delhi: Sage Publications.

Dahal, D. R. (2001). Civil Society in Nepal: Opening the Ground for Question. Kathmandu: Centre for Development and Governance.

Dahal, D. R. (2010). An enquiry into form and functions of civil society in Nepal. Vikas (Development), 3(10), A Journal of National Planning Commission, Kathmandu.

Deutsch, K. D. cited in Anand Aditya, Critical Barriers in Creating a Function State, paper presented at the seminar organized by Nepal Foundation of Advanced Studies and Friedrich Ebert Stiftung, 28 December, 2010, Kathmandu.

Ghimire, Y. R. (2012). 'HRW's Concern'. New Spotlight, Fortnightly, Jan 27-Feb, 09, 8.

Katju, M. K. (2012). Four People's Princple. The Hindu, January

Migdal, J. S. (2001). State in Society: Studying How States and Societies Transform and Constitute One Another (Cambridge Studies in Comparative Politics), Cambridge University Press.

http://dx.doi.org/10.1017/CBO9780511613067

Sachs, J. (2011). The Price of Civilisation: Economics and Ethics After the Fall. Bodley Head/Random House.

Said, E. (1996). Representation of the Intellectual: 1993 Reith Lectures, Vintage.

Shah, S. (1993). Gospel Comes to the Hindu Kingdom. Kathmandu: Himal South Asia.

Shah, S. (2008). Conflict Transformation and Democratic Consolidation: A Nepali 'Post-Conflict'. Paper presented 
in a seminar organised by Friedrich-Ebert-Stiftung, Nepal office in Sept.

Shah, S. (2003). From Evil State to Civil Society. In Kanak Mani Dixit and Shastri Ramchandra (Eds), State of Nepal. Kathmandu: Himal Books. pp.137-160.

Sharma, S. (2012). State-Society Relationship-United We Prosper. Republica National Daily, p.4.

Srivastava, A. (2012). Political crisis in Nepal: Balkanisation of nation gathers peace. Available www.vijayani.com. Accessed 23 June.

Thapar, R. (1984). From Lineage to State. New Delhi: Oxford University Press.

Upreti, P. R. (1992). Political Awakening in Nepal: The Search for a New Identity. New Delhi: Commonwealth Publishers see also Babu Ram Acharya, Aba Yasto Kahailyi Nahos (translation: Let This Not Happen Again), Kathmandu, 2055/1998.

Bhatta, Chandra D. is a Political Scientist trained at the London School of Economics and Birmingham University in the UK. He has held Research Fellowship at the George Warren Brown School of Social Work, Washington University in St. Luis, USA. His articles been appeared in the Journal of Civil Society, Asian Journal of Political Science, Journal of Peace, Conflict and Development among others. He has authored a book on Challenges of Statebuildiong in Nepal and edited number of volumes with Dev Raj Dahal and Anand Aditya. He is currently working for the Friedrich-Ebert-Stiftung, Nepal Office.

Email: chandra.bhatta@fesnepal.org 